\title{
Moral Values in Medicine and Science*
}

\author{
Ismā'il Al-Fāruqi, Ph.D.** \\ Philadelphia, Pennsylvania
}

DOI: http://dx.doi.org/10.5915/20-1-13048

The first and most basic principle of Islam is Tawhid (literally, unization), i.e., that there is no God but Allah. This principle is the foundation of the Muslim's view of life, of the world, of reality of knowledge. It is crucially relevant for every aspect of Muslim thought, every field of Muslim endeavor. An epistemological principle, the notion of the absolute unity of Allāh binds all truth to one source, whether that source be its creator as in the case of the truth of nature, or its revealer as in the case of ethical and religious truth. The unity of sources is equivalent to the unity of truth. As nature and religion are all Allāh's, there cannot be, from the standpoint of Islam, any difference, discrepancy or contradiction between the truth of what Allāh has created and that of what He had revealed. This does not mean that Man may not mistake the one, the other or both. But it does mean that what is thus mistakable is corrigible with reference to itself or to the other with further study, elucidation and substantiation. For the unity of truth is like the unity of Allāh, absolute. It assumes that truth is, knowable, and that its two realms - the one known empirically and the other intuitively - cannot ever be contradictory with, or indifferent to each other. This conclusion has been the first principle of Islamic intellectual life.

Whether a physician, an astronomer or a jurist, the Muslim conducted his enquiry as a branch of one and the same discipline, namely discovery of the truth which is Allāh's. His appetite was voracious and fastidious. Nothing of the scientific legacy of the Greeks escaped him, and he pushed the frontiers of scientific knowledge to regions, most of which only. this or the last century has transcended. Science, or pursuit of the truth of nature, was for him not only innocent, but a supreme virtue. No doubt ever beset

* The original article was published in J.I.M.A. (1977) pp 22-23

Professor, Department of Religion, Head, Section of Islamic Studies, Temple University, Philadelphia, $P A$.

** Deceased 5/27/86. him - as it did with the Greeks - that they were competing with divinity; or, as it did with the Jews and Christians, that they were either violating "the tree of knowledge" or researching a realm totally removed from the ethical and religious commandments of Allah. On the contrary, to uncover the secrets of nature is for him to learn the "sunan" (patterns) of Allāh's will, and hence to glorify Him. It is as if Allāh has granted man two roads to knowledge of Him: the easy and short road of revelation, open to and reachable by all men, and the harder and longer road of science, open to and reachable by the curious. In the former case man is passive. He "hears" what is communicated from above. Implanted in him at birth as a "Fițrah" (innate faculty) enabling him to discern the true from the false by measuring the content and form of the communication against "Dīn-al-Fițrah" (religio-naturalis) already in him. In the latter case, man is active. He senses the phenomena of nature and must relate its various parts in order to understand its patterns, i.e. laws of nature. Here, again, man is endowed with a faculty, reason, whose laws oversee and correct his relating of natural phenomena. Unlike Din-al-Fitrah, this faculty does not supply data - which have to come from nature - but a methodology whose violation is a guarantee of error and non-truth, but compliance with which is not guarantee of truth unless it is matched by a compliance with religio naturalis or ethical and religious truth.

Traditionally, the Muslim spoke of a "Two Books"' theory of truth: (1) The Qur'ān or Book of Allăh and (2) nature, another book of Allāh. Both are equally His work, His composition: of both $\mathrm{He}$ is the author. Study of one is as meritorious as the study of the other. Only personal inclination and capacity determines choice between them.

This unity and integrity of the intellectual pursuit which also characterizes man's humanity and "khilāfah" (vicegerency) in the world on behalf of Allah - preserved the wholesomeness of both the Muslim's scientific and ethico-religious pursuits. For almost a whole millennium, Muslim science and medicine reigned unchallenged and unchallengeable. No moral or ethical consideration obstructed - nor could theoretically obstruct - their advance. 
Likewise, Muslim law and jurisprudence developed to perfection, never losing touch with its empirical ground of human relations and actual human worldly happiness. Empirical, pragmatic reasonableness was the touchstone of both, and unity of the two pursuits, their ultimate criterion and worth.

Unfortunately, the Tatar invasion from the East and the Crusades from the West helped bring the coup de grace to this tremendous flowering of civilization. Internally, pursuit of moral and religious truth (happiness, salvation) tipped the balance in its favor with the advances of a revived, leftover gnosticism, asceticism and mysticism. These were the enemies of empirical reasonableness whose fortune sank proportionately with their spread and growth. Knocked out from the religio-moral realm, reasonableness was soon to be ejected from the realm of nature and science. Algebra gave way to numerology, chemistry to alchemy, astronomy to astrology, just as jurisprudence gave way to the mystical devotions, and Qur'ānic lexicograpy and exegesis to allegorical interpretation and eisegesis. Naturally, the two pursuits were on collision courses and science and medicine were the losers.

The first half of Muslim history is without parallel. The second half, began in the eighteenth century with the reform movement of Ibn 'Abd al Wahhāb and is in full swing to the present. This second half resembles Western history since the Renaissance, where the two pursuits collide and fight with one another, but not without a significant difference. That is the fact that whereas the struggling Western scientist had no religious authority in the Christian tradition to back him up and had to be inquisitioned and/or burnt at the stake until modern times when he overthrew once and for all the power of the Church, the Muslim scientist of modern days who is struggling to shake the superstitions of mystic charlatanism masquerading as religion, has all the tradition of a millennium of harmony between religion and science and the ultimate authority of revelation i.e. the Qur'ān to defend, bless and promote his noble endeavor.

There is yet a very grave note that the present day Muslim scientist has to make, despite his good fortune. The fantastic exploits of Western science may and in fact do - allure him to follow the example of the Western scientist in his stand vis-a-vis ethicoreligious reality. For the most part, the Muslim is unaware of the nature of the history of Western science and therefore of the struggle with the real and established, dogmatic authoritarianism of the Church against which the Western scientist had to labor. He is unaware of the fact that the Western scientist had no higher authority to appeal to. That is why his success came as a necessary vanquishing and rejection of religion itself. The Muslim scientist is often unaware that this history necessitated Western man's present wanderings in nature without moral or religious guidance; that the problems of ecology, exploitation, excess and disequilibrium which modern Western societies introduced into the world are all due to this banishment of religion and morality from the pursuit of natural knowledge. Ex hypothesi, the Western scientist had bifurcated truth - and his own life in consequence - into two unrelated compartments - nature and ethics - each dominated by its own phenomena, those of nature and those of personal feeling. Obviously, the end is a divided personality, catastrophe in the realm of nature and tragedy in the realm of morals.

Islam, with its unity of truth, the unity of Allāh, is not only the reasonableness and sanity of the struggling Muslim scientist of today, but is the cure and only hope of the human scientist of the future. 